\title{
Dinamika dan Proyeksi Perubahan Tutupan Lahan serta Inkonsistensi Tata Ruang di Wilayah Pegunungan Kendeng
}

\section{Dynamics and Projections of Land Cover Changes and Spatial Plan Inconsistencies in Kendeng Mountains Region}

\author{
Andrea Emma Pravitasari ${ }^{1 *}$, Ernan Rustiadi ${ }^{1}$, Soeryo Adiwibowo $^{2}$, \\ Imelda Kusuma Wardani ${ }^{1}$, Iwan Kurniawan ${ }^{1}$ \& Alfin Murtadho ${ }^{1}$
}

\begin{abstract}
${ }^{1}$ Pusat Pengkajian Perencanaan dan Pengembangan Wilayah (P4W) LPPM - Institut Pertanian Bogor, Jalan Pajajaran, Kampus IPB Baranangsiang, Bogor 16127, Indonesia; ${ }^{2}$ Departemen Sains Komunikasi dan Pengembangan Masyarakat, Fakultas Ekologi Manusia, Institut Pertanian Bogor, Jalan Kamper Kampus IPB Dramaga, Bogor 16680, Indonesia; *Penulis korespondensi.e-mail: andreaemma84@yahoo.com
\end{abstract}

(Diterima: 27 Mei 2019; Disetujui: 30 Januari 2020)

\begin{abstract}
Kendeng is limestone mountains that stretch across the northern part of Java Island. It is located in 7 regencies in 2 provinces (Pati, Grobogan, Blora, and Rembang Regenciy in Central Java Province; and Lamongan, Bojonegoro, and Tuban Regency in East Java Province). Kendeng Mountains is rich in natural resources and biodiversity. However, the development of mining activities and other cultivation activities has led to a dynamic land cover changes and threatens to damage the karst area of Kendeng Mountains. This research aims to: (1) identify the dynamics of land cover changes (LCC) in Kendeng Mountains (1996-2016); (2) conduct projections of the LCC in 2036; and (3) analyze spatial plan inconsistencies in the region. LCC analysis was conducted with ArcGIS 10.3 software using land cover maps of 1996, 2000, 2006, 2011, and 2016 from the Ministry of Environment and Forestry. Projections of LCC in 2036 was analyzed by CA-Markov using Idrisi Selva software. Spatial plan inconsistency analysis was carried out by overlaying land cover maps with Spatial Plan (RTRW) maps. Based on CA-Markov analysis, the mining area increased from 12 ha (1996) to 1,660 ha (2016), as well as built-up area from 83,543 ha (1996) to 96,761 ha (2016). The projection of land cover change predicts that mining area and built-up area in 2036 will increase to 3,646 ha and 110,843 ha. Existing area (in 2016) which is inconsistent with the Spatial Plan is 12.3\%. Based on predicted LCC in 2036, it seems that the chances of spatial plan inconsistencies in this region will increase more in the future.
\end{abstract}

Keywords: CA-Markov, karst, limestone mountain, mining, spatial plan (RTRW).

\begin{abstract}
ABSTRAK
Kendeng merupakan pegunungan kapur yang membentang di bagian utara Pulau Jawa. Pegunungan Kendeng terletak pada tujuh kabupaten di dua provinsi (Kabupaten Pati, Kabupaten Grobogan, Kabupaten Blora, dan Kabupaten Rembang di Provinsi Jawa Tengah; Kabupaten Lamongan, Kabupaten Bojonegoro, dan Kabupaten Tuban di Provinsi Jawa Timur). Pegunungan Kendeng kaya akan sumberdaya alam dan biodiversity. Namun, berkembangnya aktivitas pertambangan dan kegiatan budidaya lainnya menyebabkan terjadinya dinamika perubahan tutupan lahan dan mengancam rusaknya kawasan karst Pegunungan Kendeng. Kajian ini bertujuan untuk: (1) mengidentifikasi perubahan tutupan lahan di Pegunungan Kendeng (1996-2016); (2) melakukan proyeksi perubahan tutupan lahan tahun 2036; dan (3) menganalisis inkonsistensi tata
\end{abstract}


ruang di wilayah tersebut. Analisis perubahan tutupan lahan dilakukan dengan software ArcGIS10.3 menggunakan peta tutupan lahan tahun 1996, 2000, 2006, 2011 dan 2016 dari KLHK (Kementerian Lingkungan Hidup dan Kehutanan). Proyeksi perubahan tutupan lahan tahun 2036 dilakukan menggunakan analisis CA-Markov dengan software Idrisi Selva. Inkonsistensi tata ruang dianalisis dengan cara overlay tutupan lahan dengan Rencana Tata Ruang Wilayah (RTRW). Hasil penelitian menunjukkan bahwa terjadi peningkatan luas kawasan pertambangan dari 12 ha (1996) menjadi 1,660 ha (2016) dan ruang terbangun dari 83,543 ha (1996) menjadi 96,761 ha (2016). Hasil proyeksi perubahan tutupan lahan memprediksikan bahwa luas kawasan pertambangan dan ruang terbangun di tahun 2036 akan meningkat hingga 3,646 ha dan 110,843 ha. Luas lahan eksisting (tahun 2016) yang inkonsisten dengan RTRW adalah sebesar 12.3\%. Dengan komposisi prediksi perubahan tutupan lahan di tahun 2036, maka peluang terjadinya inkonsistensi tata ruang di wilayah ini akan semakin meningkat di masa yang akan datang.

Kata kunci: CA-Markov, karst, Pegunungan Kendeng, pertambangan, RTRW

\section{PENDAHULUAN}

Pegunungan Kendeng merupakan hamparan perbukitan batu kapur (karst) yang membentang di bagian utara Pulau Jawa. Karst Pegunungan Kendeng membentang dari Kabupaten Rembang, Blora, Grobogan dan Pati. Secara morfologi Pegunungan Kendeng adalah kompleks perbukitan pada struktur perbukitan lipatan yang termasuk dalam Formasi Bulu, Wonocolo, Ngrayong, Tuban dan Tawun. Wilayah Pegunungan Kendeng yang dikaji dalam penelitian ini mencakup 7 kabupaten yang terletak di dua provinsi yaitu: Kabupaten Pati, Grobogan, Blora, dan Rembang di Provinsi Jateng; serta Kabupaten Bojonegoro, Lamongan, dan Tuban di Provinsi Jatim.

Pegunungan Kendeng merupakan kawasan perbukitan batu kapur yang sangat potensial untuk dijadikan sebagai kawasan pertambangan galian C (seperti garam, pasir, batu kapur, tanah liat, marmer, dan asbes) terutama semen. Wilayah karst pada Pegunungan Kendeng memiliki banyak potensi bahan tambang galian $\mathrm{C}$, sehingga wilayah tersebut tidak lepas dari upaya eksplorasi untuk aktivitas pertambangan. Banyaknya kegiatan penambangan ilegal yang tidak memperhatikan dampak yang ditimbulkan seperti kerusakan lingkungan di wilayah Pegunungan Kendeng, khususnya pada Kabupaten Pati menyebabkan terancamnya sumber air di wilayah tersebut akibat kerusakan daerah batuan karst. Kerusakan sudah mulai terlihat pada wilayah Pegunungan Kendeng Utara, dari Desa Prawoto, Kecamatan Sukolilo hingga Desa Maitan, Kecamatan Tambakromo (Hartanto \& Suyoto, 2017).

Undang-Undang Penataan Ruang (UU 26/2007) menjelaskan tujuan penataan ruang yang salah satunya adalah mewujudkan optimalisasi pemanfaatan ruang namun tetap mempertimbangkan prinsip-prinsip keberlanjutan lingkungan sehingga dampak negatif dari pemanfaatan ruang dapat dihindari atau diminimalisir. Terdapat tiga proses atau kegiatan dalam melakukan penataan ruang, yaitu: (1) perencanaan tata ruang; (2) implementasi/pemanfaatan ruang, dan (3) pengendalian pemanfaatan ruang (Hariyanto \& Tukidi, 2007). Menurut Hidayat et al. (2015), dalam pelaksanaannya, seringkali proses pemanfaatan ruang belum sepenuhnya mengikuti RTRW. Banyak masyarakat yang belum memahami tentang fungsi penting RTRW dalam penataan ruang. Hal ini yang menjadi salah satu alasan banyaknya penambang-penambang liar di wilayah Pegunungan Kendeng.

Berkembangnya berbagai aktivitas pertambangan dan kegiatan budidaya lainnya di wilayah Pegunungan Kendeng memicu terjadinya perubahan tutupan lahan. Perubahan tutupan lahan didefinisikan sebagai bertambahnya suatu jenis tutupan lahan dari 
satu jenis ke jenis tutupan lahan lainnya pada periode waktu tertentu (Pravitasari et al., 2019), dimana perubahan ini umumnya bersifat irreversible (tak dapat kembali), seperti hutan yang dikonversi ke ruang terbangun (misalnya permukiman) akan sangat sulit kemungkinannya untuk diubah menjadi lahan hutan kembali (Rustiadi, 2001 dalam Hidayat et al., 2015).

Implikasi dari eksploitasi sumberdaya alam oleh banyaknya kegiatan pertambangan pada Pegunungan Kendeng selain dapat membuat menipisnya jumlah sumber mata air, juga dapat menghilangkan kekayaan keanekaragaman hayati flora dan fauna serta kerusakan alam. Menurut Setiawan et al. (2013), kejadian bencana banjir yang sering terjadi di Kecamatan Sukolilo, Kabupaten Pati merupakan akibat dari aktivitas penambangan karst liar dan kegiatan penggundulan hutan yang semakin marak terjadi di Pegunungan Kendeng Utara, yang memicu degradasi hutan dan meningkatnya lahan kritis di kawasan hutan Kabupaten Pati. Dengan demikian, analisis dinamika perubahan penggunaan lahan menjadi penting untuk dilakukan (Widjayatnika et al., 2017).

Berbagai pernyataan latar belakang sebelumnya menyebabkan munculnya suatu pertanyaan penelitian mengenai "apakah terjadi perubahan tutupan lahan dan inkonsistensi tata ruang di wilayah Pegunungan?" Dari pertanyaan penelitian tersebut menyebabkan perlu adanya penelitian mengenai dinamika dan proyeksi perubahan tutupan lahan serta inkonsistensi tata ruang di wilayah Pegunungan Kendeng sehingga tujuan dari penataan ruang melalui RTRW dapat terwujud. Kajian ini bertujuan untuk: (1) mengidentifikasi perubahan tutupan lahan di Pegunungan Kendeng (1996-2016); (2) melakukan proyeksi perubahan tutupan lahan tahun 2036; dan (3) menganalisis inkonsistensi tata ruang di wilayah tersebut.

\section{METODOLOGI}

Peta-peta yang digunakan pada kajian ini meliputi: peta tutupan lahan (tahun 1996, 2000, 2006, 2011, dan 2016 hasil interpretasi LANDSAT) dari Direktorat Jenderal Planologi Kehutanan dan Tata Lingkungan, KLHK; peta administrasi 7 kabupaten yaitu: Kabupaten Blora, Pati, Grobogan, Rembang, Lamongan, Bojonegoro, dan Tuban; peta batas wilayah Pegunungan Kendeng; Peta RTRW Provinsi Jateng dan Jatim. Perangkat lunak yang digunakan pada kajian ini adalah Microsoft Office, ArcGIS 10.3 dan Idrisi 17.0 The Selva Edition.

\section{Metode Penelitian}

1. Dinamika Perubahan Tutupan Lahan 19962016

Klasifikasi tutupan lahan dari KLHK digeneralisasi menjadi enam jenis tutupan lahan yaitu hutan, ruang terbangun, sawah, pertambangan, badan air, dan pertanian lainnya. Kemudian dihitung luas per tutupan lahan per tahun. Luas tutupan lahan di wilayah agregat dan Pegunungan Kendeng dibandingkan pada setiap titik tahun pengamatan.

2. Proyeksi Tutupan Lahan Tahun 2036

Proyeksi tutupan lahan dianalisis dengan model CA-Markov (Cellular Automata-Markov) dengan software IDRISI 17.0 The Selva Edition. Metode ini merupakan teknik analisis yang digunakan untuk memperkirakan perubahan tutupan lahan di waktu mendatang dengan menghitung probabilitas perubahan tutupan lahan dari waktu ke waktu. Cellular Automata merupakan pemodelan berbasis grid atau sel, dimana inti dari sel berinteraksi dengan sel tetangganya. Cellular Automata menjadi metode yang sering digunakan dalam pemodelan interaksi spasial, terutama untuk membuat model penggunaan/penutupan lahan (Kurnianti, 2015). Titik tahun yang digunakan untuk memproyeksi tutupan lahan 2036 adalah tahun 1996, 2006, dan 2016. 
Hasil analisis dari metode markov chain markov transition probabilities (Gambar 1 dan akan menghasilkan markov transition areas dan Gambar 2).

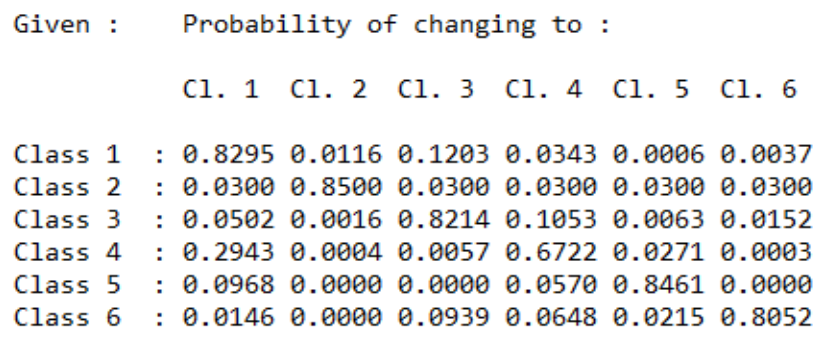

Gambar 1. Markov transition probabilities pada tutupan lahan 2016

Kells in: Expected to transition to :

\begin{tabular}{|c|c|c|c|c|c|c|c|}
\hline & & Cl. 1 & Cl. 2 & Cl. 3 & Cl. 4 & Cl. 5 & Cl. 6 \\
\hline Class 1 & : & 424645 & 5917 & 61605 & 17561 & 318 & 1876 \\
\hline Class 2 & : & 32 & 908 & 32 & 32 & 32 & 37 \\
\hline Class 3 & : & 36878 & 1175 & 603451 & 77353 & 4610 & 11189 \\
\hline Class 4 & : & 51620 & 63 & 1001 & 117913 & 4757 & 58 \\
\hline Class 5 & : & 10298 & 0 & 0 & 6066 & 89999 & \\
\hline Class 6 & : & 333 & 0 & 2137 & 1474 & 490 & 18327 \\
\hline
\end{tabular}

(Ket: $\mathrm{Cl}=$ class; $\mathrm{Cl} .1=$ Hutan; $\mathrm{Cl} .2=$ Pertambangan; $\mathrm{Cl} .3=$ Sawah; $\mathrm{Cl} .4=$ Pertanian lainnya; $\mathrm{Cl} .5=$ Ruang Terbangun; Cl.6=Badan Air)

Gambar 2 Markov transition areas pada tutupan lahan 2016

Diperlukan suatu tahap validasi sebelum dapat membuat model dari tutupan lahan tahun 2036. Tahap validasi merupakan kuantifikasi kemiripan peta hasil proyeksi dengan peta aktual, atau peta proyeksi tahun 2016 memiliki kemiripan dengan peta aktual tahun 2016. Setelah proses validasi menghasilkan indeks Kappa $>0.85$ maka tahapan selanjutnya adalah melakukan analisis markov chain terhadap peta tutupan lahan 1996 dengan 2016 yang akan menghasilkan peta proyeksi tutupan lahan tahun 2036.

Inkonsistensi Tutupan Lahan 2016 dengan RTRW Provinsi Jateng-Jatim dan Peluang Inkonsistensi Tutupan Lahan 2036* dengan RTRW Provinsi Jateng-Jatim
Peta tutupan lahan tahun 2016 dan proyeksi tahun 2036 ditumpangsusunkan dengan Peta RTRW Provinsi Jateng-Jatim. Setelah itu data dianalisis dalam aspek kesesuaian tutupan lahan dengan RTRW Provinsi Jateng-Jatim dengan memperhatikan matriks sintesis konsistensi dan inkonsistensi pada Tabel 1. Jika kondisi tutupan lahan masih selaras dengan rencana pola ruang yang terdapat pada RTRW, maka dikatakan bahwa pemanfaatan ruangnya (tutupan lahan) konsisten. Jika sebaliknya, maka dikatakan tidak konsisten (inkonsistensi tata ruang).

Tabel 1. Matriks inkonsistensi tutupan lahan hasil proyeksi tahun 2036 dengan Rencana Tata Ruang Wilayah Provinsi Jawa Tengah dan Jawa Timur

\begin{tabular}{|c|c|c|c|c|c|c|c|}
\hline \multirow[b]{2}{*}{ Tutupan Lahan } & \multicolumn{7}{|c|}{ Pola Ruang } \\
\hline & 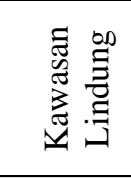 & 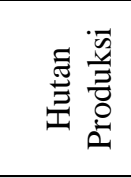 & 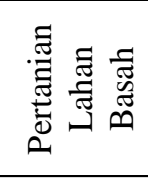 & 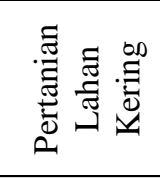 & 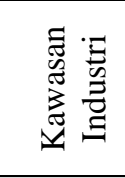 & 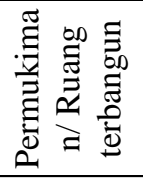 & 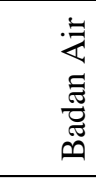 \\
\hline Hutan & $\mathrm{O}$ & $\mathrm{O}$ & $\mathrm{O}$ & $\mathrm{O}$ & $\mathrm{O}$ & $\mathrm{O}$ & $\mathrm{O}$ \\
\hline Ruang terbangun & - & - & - & - & $\mathrm{O}$ & $\mathrm{O}$ & - \\
\hline Sawah & - & - & $\mathrm{O}$ & $\mathrm{O}$ & $\mathrm{O}$ & $\mathrm{O}$ & $\mathrm{O}$ \\
\hline Badan Air & - & - & - & - & - & - & $\mathrm{O}$ \\
\hline Pertambangan & - & - & - & - & $\mathrm{O}$ & $\mathrm{O}$ & $\mathrm{O}$ \\
\hline Pertanian Lainnya & - & - & $\mathrm{O}$ & $\mathrm{O}$ & $\mathrm{O}$ & $\mathrm{O}$ & $\mathrm{O}$ \\
\hline
\end{tabular}

Keterangan: $\mathrm{O}=$ konsisten, - = inkonsisten 


\section{HASIL DAN PEMBAHASAN}

1. Dinamika Perubahan Tutupan Lahan Pegunungan Kendeng Tahun 1996-2016

Kendeng adalah pegunungan karst yang terbentang dari Provinsi Jateng hingga Provinsi Jatim. Kendeng diidentifikasi berdasarkan adanya potensi batu gamping atau batu kapur dan terletak pada ketinggian $100 \mathrm{mdpl}$.

Tutupan lahan didefinisikan sebagai kondisi kenampakan biofisik di permukaan bumi yang diamati dan menggambarkan konstruksi vegetasi dan buatan yang menutup permukaan lahan (Burley, 1961 dalam Lo, 1995), serta merupakan hasil pengaturan, aktivitas, dan perlakuan manusia pada jenis penutup lahan tertentu untuk melakukan kegiatan produksi, perubahan, maupun perawatan pada areal tersebut (BSN, 2010). Sementara itu, yang dimaksud dengan perubahan tutupan lahan adalah keadaan suatu lahan yang mengalami perubahan kondisi pada periode waktu tertentu akibat perbuatan manusia (Lillesand \& Kiefer, 1990).

Tutupan lahan pada wilayah penelitian diklasifikasikan ke dalam enam jenis, yaitu hutan, ruang terbangun, sawah, badan air, pertambangan, dan pertanian lainnya. Tutupan lahan dianalisis pada beberapa titik tahun yaitu 1996, 2000, 2006, 2011, dan 2016. Peta tutupan lahan tahun 1996, 2000, 2006, 2011, dan 2016 disajikan pada Gambar 4.

Peta yang disajikan pada Gambar 4 menunjukkan dinamika perubahan tutupan lahan selama periode tahun 1996-2016. Penjabaran luas tutupan lahan di wilayah agregat (Kabupaten Blora, Grobogan, Pati, Rembang, Lamongan Bojonegoro, dan Tuban) pada masing-masing tahun disajikan pada Tabel 2 sedangkan grafik luas tutupan lahan (\%) pada beberapa titik tahun disajikan pada Gambar 3a.

Tabel 2. Tutupan lahan dan luas agregat di tujuh kabupaten di wilayah Pegunungan Kendeng (wilayah agregat)

\begin{tabular}{lllllll}
\hline \multirow{2}{*}{ No. } & \multirow{2}{*}{ Tutupan Lahan } & \multicolumn{5}{l}{ Luas (ha) pada Tahun } \\
\cline { 3 - 6 } & & 1996 & 2000 & 2006 & 2011 & 2016 \\
\hline 1 & Hutan & 387,790 & 415,486 & 414,891 & 412,730 & 405,833 \\
2 & Ruang terbangun & 83,543 & 84,098 & 86,741 & 86,965 & 96,761 \\
3 & Sawah & 610,898 & 601,891 & 597,976 & 598,109 & 585,449 \\
4 & Pertambangan & 12 & 610 & 877 & 976 & 1,660 \\
5 & Badan Air & 17,469 & 17,948 & 18,532 & 18,532 & 19,501 \\
6 & Pertanian Lainnya & 162,713 & 142,392 & 143,408 & 145,114 & 153,220 \\
\hline Jumlah (ha) & $1,262,425$ & $1,262,425$ & $1,262,425$ & $1,262,425$ & $1,262,425$ \\
\hline
\end{tabular}

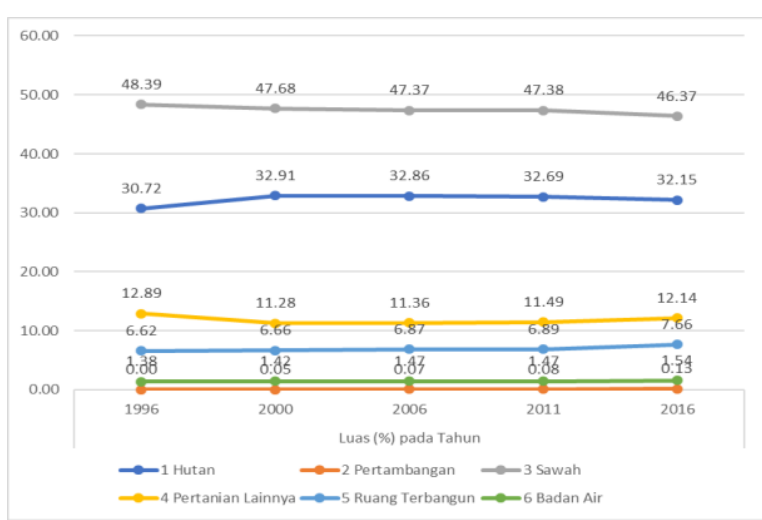

(a)

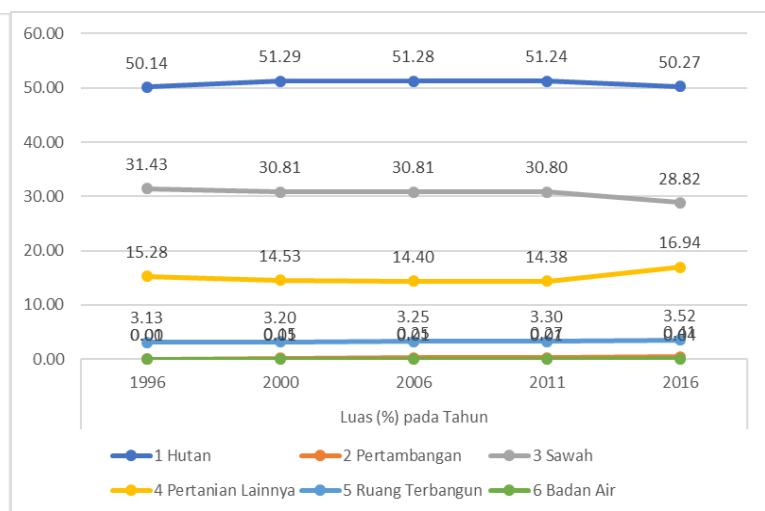

(b)

Gambar 3. Tren perubahan tutupan lahan tahun 1996-2016 pada (a) wilayah agregat

(b) Pegunungan Kendeng 


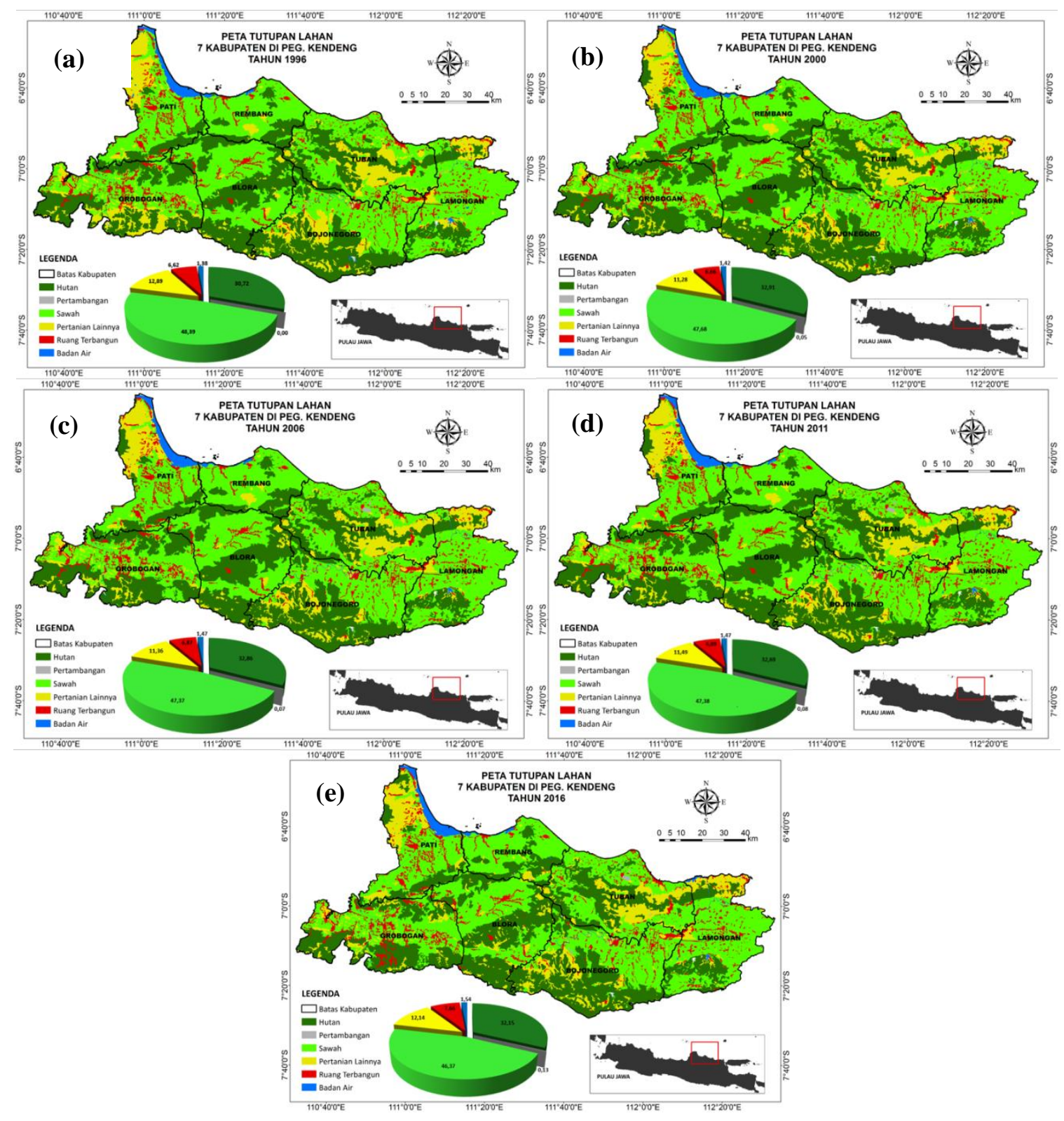

Gambar 4. Peta tutupan lahan yang di wilayahnya terdapat Pegunungan Kendeng (wilayah agregat): (a) Tahun 1996; (b) 2000; (c) 2006; (d) 2011; dan (e) 2016

Luas wilayah agregat (tujuh kabupaten) adalah 1,262,425 ha. Berdasarkan Tabel 2, secara keseluruhan keadaan penutupan lahan di sekitar pegunungan Kendeng (wilayah agregat) di lima titik tahun menunjukkan dinamika perubahan. Penutupan lahan hutan dari tahun 1996 hingga 2000 mengalami peningkatan sedangkan pada tahun 2000 hingga 2016 menunjukkan tren penurunan luas lahan hutan. Menurut info dari hasil observasi lapang, peningkatan luas hutan dari tahun 1996 ke tahun 2000 disebabkan karena masyarakat yang tinggal di wilayah Pegunungan Kendeng banyak melakukan penanaman pohon jati dan pohon sengon. Hal tersebut yang menyebabkan luasan tutupan lahan hutan bertambah. Namun, pada periode waktu berikutnya luas hutan terus mengalami penurunan, terutama karena banyak masyarakat yang kemudian beralih ke usaha pertambangan. Luas lahan untuk kegiatan pertambangan semakin meningkat yaitu dari 12 ha menjadi 1,660 ha atau meningkat sebanyak 1,648 ha dalam waktu 20 tahun. Luas penutupan lahan sawah cenderung menurun sebanyak 25,449 ha. Pada tahun 1996 ke 2000, pertanian lainnya mengalami penurunan yang 
cukup luas namun pada tahun-tahun berikutnya luas lahan pertanian lainnya kembali meningkat. Ruang terbangun mempunyai luasan yang banyak meningkat yaitu dari 83,543 ha menjadi 96,761 ha (mengalami peningkatan sebanyak $15.82 \%)$. Luas badan air juga mengalami peningkatan. Peningkatan luas badan air dapat disebabkan oleh penambahan luas tambak.

Selain penjabaran tutupan lahan di wilayah agregat, tutupan lahan di wilayah Pegunungan Kendeng juga disajikan pada Tabel 3 dan Gambar 3b. Pegunungan Kendeng menempati $21.83 \%$ dari wilayah agregat. Berdasarkan data tahun 2016, tutupan lahan paling luas adalah hutan (138,532 ha), kemudian diikuti oleh tutupan lahan sawah $(79,417 \mathrm{ha})$, pertanian lainnya (46,684 ha) dan ruang terbangun (9,705 ha). Sementara itu, dua tutupan lahan sisanya yakni pertambangan, dan badan air, masing-masing memiliki luas 1,140 ha dan 104 ha. Jika ditinjau dari tutupan lahan wilayah agregat (7 kabupaten), proporsi luas tutupan lahan pegunungan Kendeng dibandingkan dengan luas tutupan lahan wilayah agregat (7 kabupaten) adalah sebagai berikut. Hutan di Pegunungan Kendeng seluas $34.13 \%$ dari luas tutupan hutan di wilayah agregat; pertambangan memiliki proporsi $68.69 \%$ dari wilayah agregat; proporsi sawah $13.56 \%$ dari wilayah agregat; pertanian lainnya seluas $30.47 \%$ dari wilayah agregat; ruang terbangun memiliki proporsi $10.03 \%$ dari wilayah agregat; dan badan air hanya seluas $0.53 \%$ dari wilayah agregat. Berdasarkan data tersebut dapat diketahui bahwa kegiatan pertambangan paling banyak dilakukan di Pegunungan Kendeng dan perkiraan bahan tambang yang banyak diambil adalah batu kapur atau batu gamping. Laju pertambahan tutupan lahan pertambangan dapat dikatakan sangat tinggi. Hal tersebut dapat menggambarkan wilayah Pegunungan Kendeng banyak diusahakan menjadi pertambangan. Badan air di Pegunungan Kendeng juga jauh lebih sempit daripada wilayah agregat. Luas tersebut menunjukkan keterkaitan wilayah Pegunungan Kendeng yang berada di topografi lebih tinggi dibandingkan dengan wilayah agregat dengan ketinggian yang beragam.

Tabel 3. Tutupan lahan dan luas keseluruhan di Pegunungan Kendeng

\begin{tabular}{lllllll}
\hline \multirow{2}{*}{ No. } & \multirow{2}{*}{ Tutupan Lahan } & \multicolumn{4}{l}{ Luas (ha) pada tahun } \\
\cline { 3 - 6 } & & 1996 & 2000 & 2006 & 2011 & 2016 \\
\hline 1 & Hutan & 138,187 & 141,346 & 141,306 & 141,198 & 138,532 \\
2 & Ruang terbangun & 8,631 & 8,821 & 8,945 & 9,085 & 9,705 \\
3 & Sawah & 86,622 & 84,919 & 84,919 & 84,880 & 79,417 \\
4 & Pertambangan & 3 & 414 & 680 & 748 & 1,140 \\
5 & Badan Air & 39 & 39 & 39 & 39 & 104 \\
6 & Pertanian Lainnya & 42,100 & 40,042 & 39,691 & 39,631 & 46,684 \\
\hline Jumlah (ha) & 275,581 & 275,581 & 275,581 & 275,581 & 275,581 \\
\hline
\end{tabular}

\section{Proyeksi Tutupan Lahan Tahun 2036}

Proyeksi tutupan lahan pada tahun 2036 menggunakan data titik tahun 1996, 2006, dan 2016. Model menunjukkan Nilai Kappa sebesar 0.8875 , dimana nilai tersebut menunjukkan nilai validasi yang sangat kuat (Nurwanda, 2016) dan akurasi yang baik (Kurniawan et al., 2017) karena melebihi nilai minimal 0.85 . Setelah mendapatkan nilai validasi yang cukup tinggi, dilakukan proyeksi tutupan lahan tahun 2036 dengan Cellular Automata Markov. Hasil proyeksi disajikan pada Gambar 5 dan Tabel 4 (wilayah agregat) serta Gambar 6 dan Tabel 5 (wilayah Pegunungan Kendeng). 


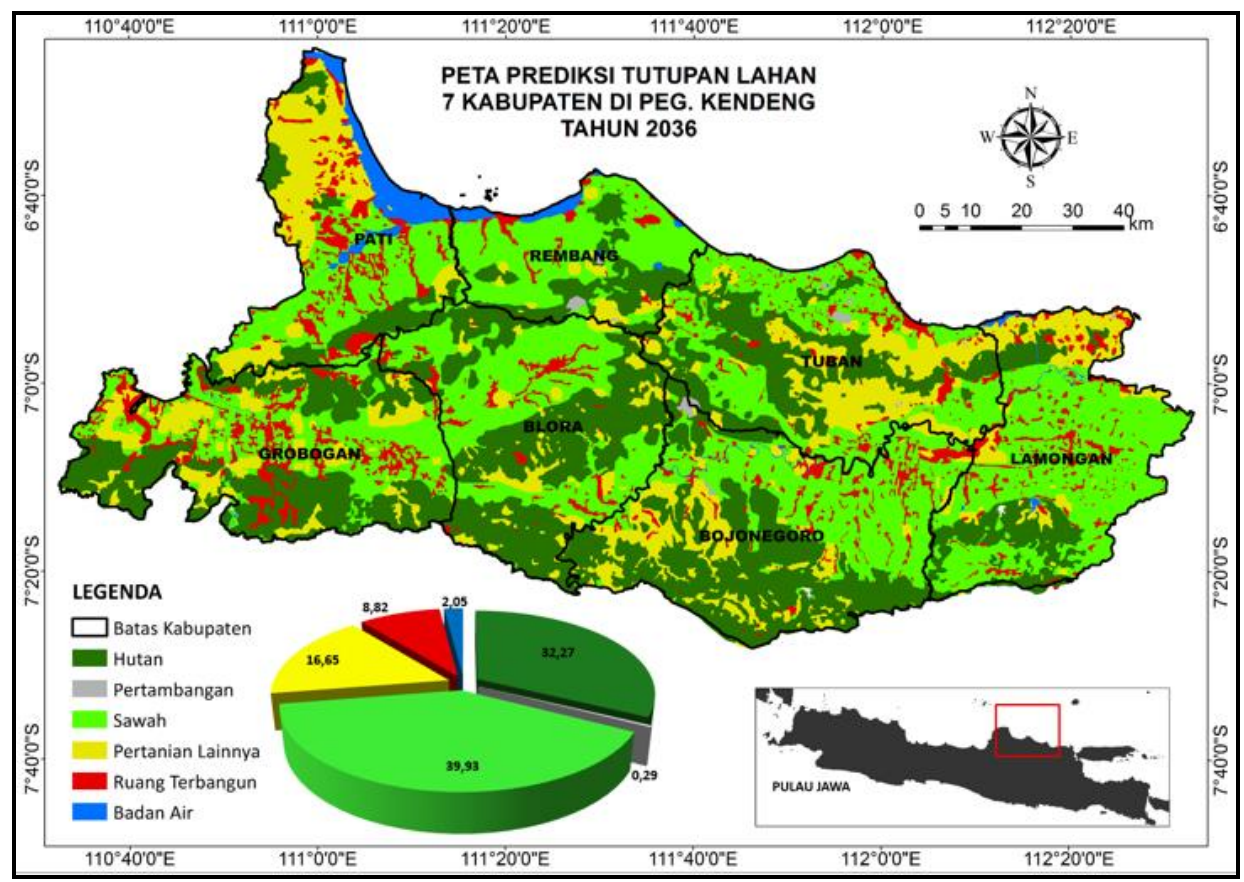

Gambar 5. Peta proyeksi tutupan lahan tahun 2036 di wilayah agregat

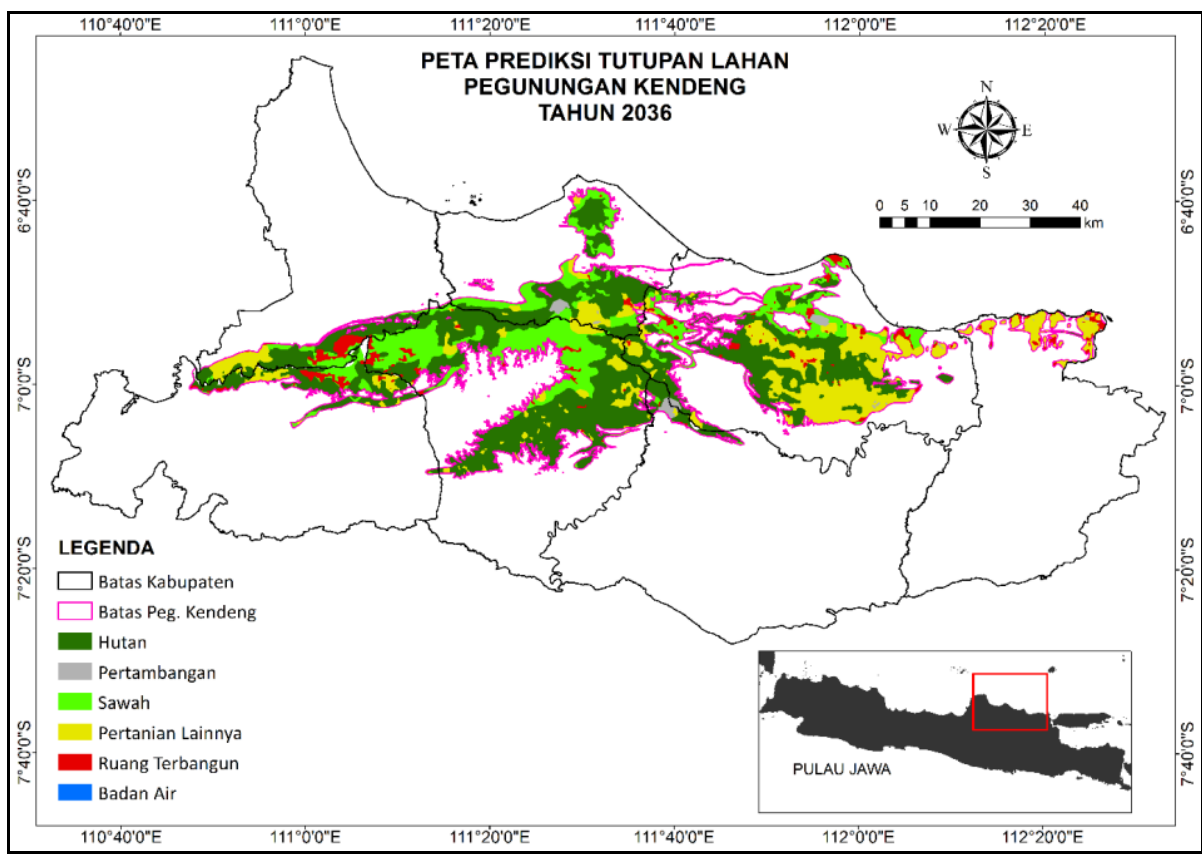

Gambar 6. Peta hasil proyeksi tutupan lahan tahun 2036 di wilayah Pegunungan Kendeng

Tabel 4. Penutupan lahan di wilayah agregat tahun 2036 hasil proyeksi CA-Markov

\begin{tabular}{lllc}
\hline No & Tutupan Lahan & Luas (ha) & Persentase (\%) \\
\hline 1 & Hutan & 407,350 & 32.27 \\
2 & Ruang terbangun & 111,294 & 8.81 \\
3 & Sawah & 504,026 & 39.93 \\
4 & Pertambangan & 3,661 & 0.29 \\
5 & Badan Air & 25,865 & 2.05 \\
6 & Pertanian Lainnya & 210,229 & 16,65 \\
\hline Jumlah (ha) & & $1,262,425$ & 100.00 \\
\hline
\end{tabular}


Hasil proyeksi tutupan lahan hutan relatif tidak berubah dari periode tahun 2016 hingga 2036. Areal pertambangan mengalami peningkatan luasan menjadi 3,646 ha pada wilayah agregat (7 kabupaten), sedangkan di pegunungan Kendeng meluas hingga 2,776 ha (76\% dari wilayah agregat). Penutupan lahan sawah diproyeksi mengalami penyusutan menjadi 501,980 ha (wilayah agregat) dan 62,244 ha (Pegunungan Kendeng). Secara lebih jelas, perubahan tutupan lahan yang akan terjadi

pada tahun 2036 dari tahun 2016 disajikan pada Tabel 6 dan Gambar 7.

Tabel 5. Penutupan lahan hasil proyeksi tahun 2036 di Pegunungan Kendeng

\begin{tabular}{llrl}
\hline No & Tutupan Lahan & Luas (ha) & $\begin{array}{l}\text { Persentase } \\
(\%)\end{array}$ \\
\hline 1 & Hutan & 138,509 & 50.26 \\
2 & Ruang terbangun & 12,943 & 4.70 \\
3 & Sawah & 62,628 & 22.73 \\
4 & Pertambangan & 2,793 & 1.01 \\
5 & Badan Air & 99 & 0.03 \\
6 & Pertanian Lainnya & 58,609 & 21.27 \\
\hline Jumlah (ha) & 275,581 & 100.00 \\
\hline
\end{tabular}

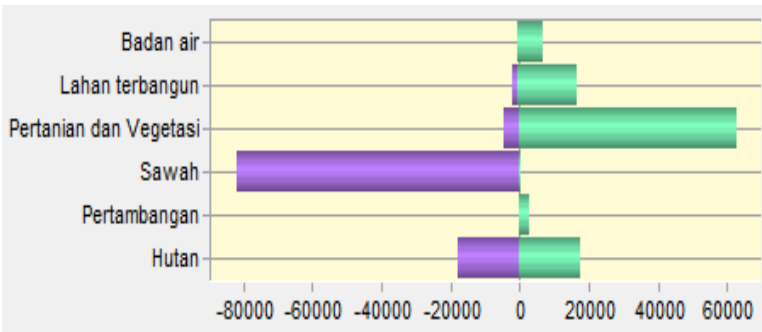

(a)

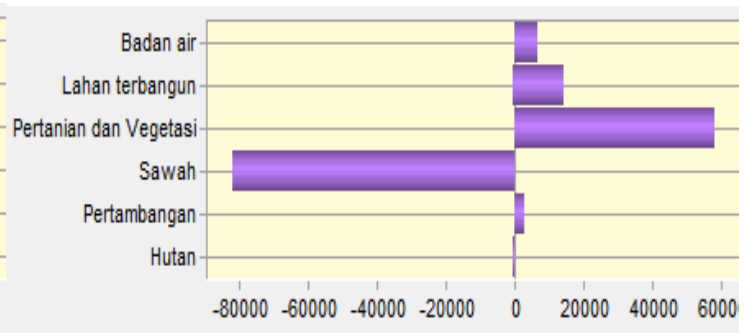

(b)

Gambar 7. (a) Penambahan dan Pengurangan luas tutupan lahan 2016-2036; dan

(b) Perubahan luas (netto) tutupan lahan dari tahun 2016 ke 2036

Tabel 6. Perubahan tutupan lahan 2016 dan proyeksi 2036 di Pegunungan Kendeng

\begin{tabular}{|c|c|c|c|}
\hline $\begin{array}{l}\text { Perubahan } \\
\text { dan proyeksi } 2036\end{array}$ & lahan & \multirow{2}{*}{$\begin{array}{l}\text { Luas } \\
\text { (ha) }\end{array}$} & \multirow{2}{*}{$\begin{array}{l}\text { Persentase } \\
(\%)\end{array}$} \\
\hline 2016 & 2036 & & \\
\hline Hutan & Ruang terbangun & 2,182 & 9.20 \\
\hline Hutan & Pertambangan & 1,645 & 6.93 \\
\hline Hutan & Pertanian Lainnya & 2,684 & 11.31 \\
\hline Sawah & Hutan & 6,375 & 26.87 \\
\hline Sawah & Badan Air & 19 & 0.08 \\
\hline Sawah & Pertambangan & 1 & 0.01 \\
\hline Sawah & Ruang terbangun & 501 & 2.11 \\
\hline Sawah & Pertanian Lainnya & 9,648 & 40.67 \\
\hline Pertanian Lainnya & Hutan & 4 & 0.02 \\
\hline Pertanian Lainnya & Ruang terbangun & 647 & 2.73 \\
\hline Badan Air & Pertanian Lainnya & 18 & 0.07 \\
\hline Total luas (ha) & & 23,723 & 100.00 \\
\hline
\end{tabular}

Tutupan lahan diproyeksi mengalami perubahan pada tahun 2016 ke 2036 di Pegunungan Kendeng adalah tutupan lahan hutan, sawah, pertanian lainnya, dan badan air. Lahan hutan diproyeksi akan banyak berubah fungsi menjadi lahan pertambangan, pertanian lainnya, dan ruang terbangun. Perubahan lahan hutan menjadi pertambangan cukup tinggi yaitu seluas 1,645 ha. Dari Tabel 6 dapat dilihat bahwa lahan sawah banyak mengalami perubahan fungsi menjadi hutan tanaman, ruang terbangun, dan pertanian lainnya. Hutan tanaman dapat dimiliki oleh individu atau masyarakat banyak. Sawah dapat berubah menjadi jenis pertanian lahan kering. Salah satu faktor yang mendorong terjadinya konversi lahan adalah meningkatnya populasi penduduk (Ricky et al., 2017). Pertumbuhan jumlah penduduk ini mengakibatkan tingginya permintaan terhadap ruang sehingga proses konversi lahan sawah menjadi ruang terbangun (permukiman) banyak terjadi. Berdasarkan hasil 
proyeksi, lahan pertanian lainnya akan banyak berpeluang untuk terkonversi menjadi lahan hutan dan ruang terbangun.

3. Inkonsistensi Tutupan Lahan 2016 dengan RTRW Provinsi Jateng-Jatim serta Peluang Inkonsistensi Tutupan Lahan Proyeksi Tahun 2036 dengan RTRW Provinsi JatengJatim

Hasil overlay antara peta tutupan lahan aktual 2016 maupun proyeksi tahun 2036 dengan peta RTRW Provinsi Jateng dan Jatim digunakan untuk mengetahui inkonsistensi antara pemanfaatan ruang (tutupan lahan eksisting) dengan pola ruang RTRW. Analisis ini bertujuan untuk mengevaluasi sejauh mana konsistensi dalam implementasi/pemanfaatan ruang sesuai dengan RTRW (Kementerian Pekerjaan Umum/PU, 2010).

a. Inkonsistensi Tutupan Lahan tahun 2016 dengan RTRW Provinsi Jateng dan Jatim

Peta inkonsistensi antara tutupan lahan eksisting tahun 2016 dengan RTRW Provinsi Jateng dan Jatim disajikan pada Gambar 8 . Penjabaran inkonsistensi tutupan lahan disajikan pada Tabel 7. Pada wilayah agregat terjadi inkonsistensi antara tutupan lahan dengan RTRW seluas 156,160 ha atau $12.37 \%$. Inkonsistensi lahan yang paling besar terjadi pada jenis tutupan ruang terbangun, sawah, dan pertanian lainnya yakni sebesar $91.57 \%$ dari luas inkonsistensi total, dimana pada RTRW areal tersebut dialokasikan untuk hutan produksi dan sawah atau pertanian lahan basah.

Inkonsistensi antara pemanfaatan ruang dan rencana pola ruang RTRW di Pegunungan Kendeng adalah $16.80 \%$ atau $29.65 \%$ dari wilayah agregat. Artinya sekitar 29.65\% inkonsistensi pemanfaatan lahan wilayah agregat terjadi di wilayah Pegunungan Kendeng. Inkonsistensi tersebut dominan terjadi pada sawah dan pertanian lainnya yang pada RTRW seharusnya berada di kawasan lindung dan hutan produksi.

Tabel 7. Inkonsistensi tutupan lahan tahun 2016 dengan RTRW Provinsi Jateng dan Jatim

\begin{tabular}{llll}
\hline Tutupan Lahan 2016 & RTRW & Luas (ha)* & Luas (ha)** \\
\hline Ruang terbangun & Kawasan Lindung & 3,417 & 904 \\
& Hutan Produksi & 3,914 & 891 \\
& Pertanian Lahan Kering & 8,344 & 1,793 \\
& Sawah/Pertanian Lahan Basah & 36,450 & 2,770 \\
\hline Sawah & Kawasan Lindung & 19,091 & 9,865 \\
& Hutan Produksi & 34,569 & 12,311 \\
\hline Pertambangan & Kawasan Lindung & 46 & 17 \\
& Hutan Produksi & 571 & 571 \\
& Pertanian Lahan Kering & 153 & 143 \\
& Sawah/Pertanian Lahan Basah & 592 & 224 \\
\hline Badan Air & Hutan Produksi & 311 & 4 \\
& Kawasan Lindung & 1,406 & - \\
& Kawasan Peruntukan Industri & 123 & 2 \\
& Ruang terbangun & 2,437 & 0 \\
& Pertanian Lahan Kering & 756 & 4 \\
& Sawah/Pertanian Lahan Basah & 6,764 & 94 \\
\hline Pertanian Lainnya & Kawasan Lindung & 12,117 & 4,611 \\
& Hutan Produksi & 25,100 & 12,094 \\
\hline Luas Inkonsistensi (ha) & & 156,160 & 46,298 \\
\hline
\end{tabular}

Keterangan: *Wilayah Agregat **Pegunungan Kendeng 


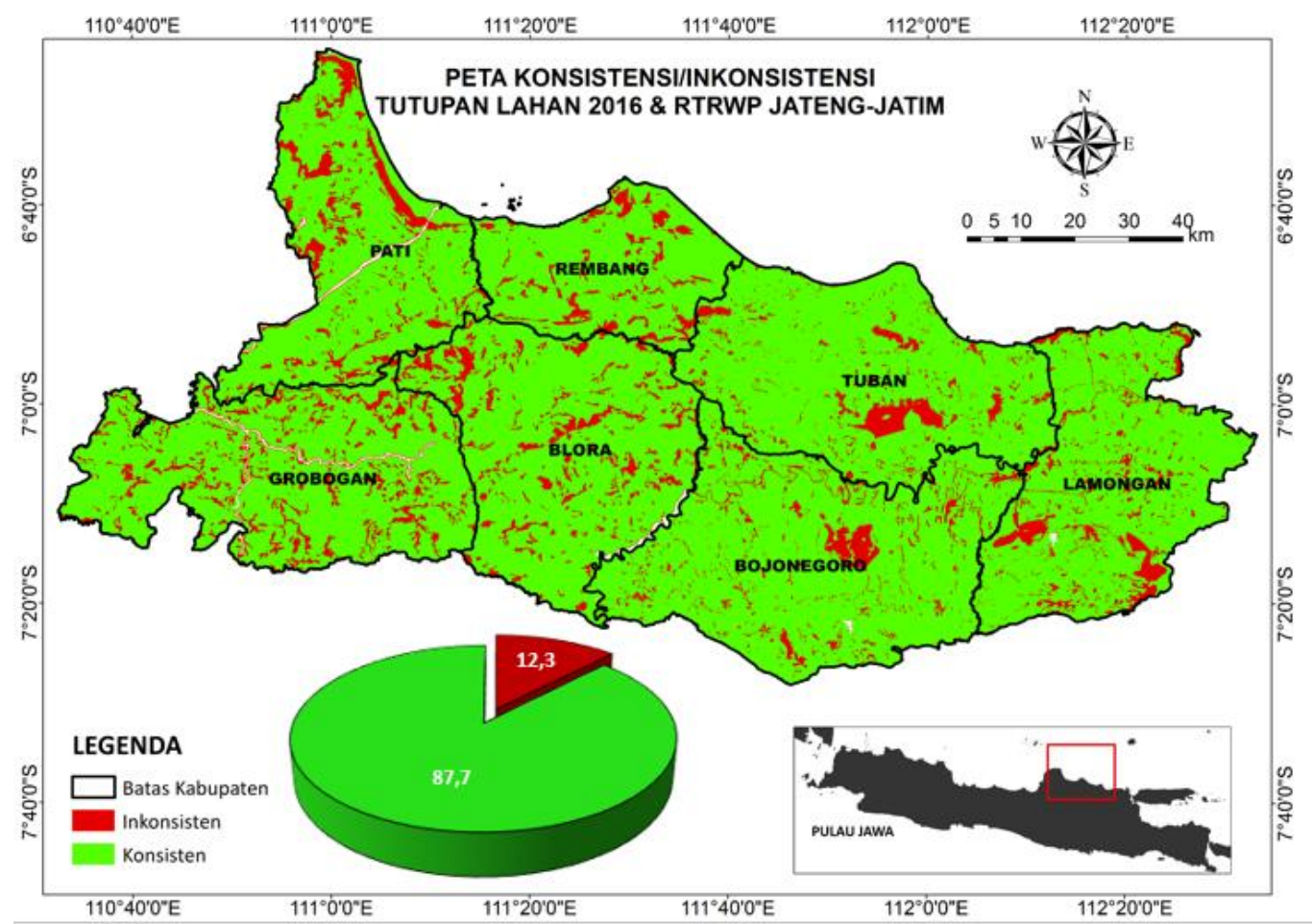

Gambar 8. Inkonsistensi tutupan lahan tahun 2016 dengan RTRW Provinsi Jateng-Jatim

Berdasarkan hasil analisis tersebut juga dapat dijelaskan bahwa beberapa kegiatan pertambangan baik yang ada di wilayah agregat maupun Pegunungan Kendeng dilakukan di lahan yang peruntukannya bukan pertambangan. Pada wilayah agregat, seluas 1,362 ha tutupan lahan pertambangan tidak sesuai dengan rencana pola ruang yang ada. Inkonsistensi pertambangan adalah $82.05 \%$ dari pertambangan total yang ada di wilayah agregat. Inkonsistensi lahan pertambangan terhadap rencana pola ruang di Pegunungan Kendeng adalah 955 ha atau menyumbang sebanyak $70.12 \%$ terhadap inkonsistensi pertambangan di wilayah agregat.

b. Peluang Inkonsistensi Tutupan Lahan Tahun 2036* dengan Rencana Tata Ruang Wilayah Provinsi Jateng-Jatim

Peta peluang inkonsistensi tutupan lahan tahun 2036* dengan RTRW Provinsi Jateng dan Jatim disajikan pada Gambar 9. Penjabaran peluang inkonsistensi tutupan lahan proyeksi tahun 2036 disajikan pada Tabel 8. Peluang inkonsistensi tata ruang tahun 2036 adalah $13.5 \%$ (170,060 ha). Inkonsistensi terbesar terjadi pada tutupan lahan ruang terbangun (62,049 ha), pertanian lainnya (48,586 ha), dan sawah (38,959 ha). Peningkatan jumlah penduduk dan tingkat perkembangan wilayah dapat menjadi faktor pendorong perubahan tutupan lahan (terutama sawah dan lahan pertanian menjadi permukiman atau ruang terbangun lainnya) yang sangat berpeluang menyebabkan terjadinya inkonsistensi tata ruang, seperti halnya yang dijumpai dari beberapa penelitian (Azadi et al., 2011; Firman 2000; 2004; Jing et al., 2018; Lamidi et al., 2017; Mulya et al., 2019).

Peluang terjadinya inkonsistensi pada Pegunungan Kendeng tahun 2036 adalah sebesar $17.53 \%$ dimana nilai ini meningkat $0.73 \%$ dari inkonsistensi tutupan lahan tahun 2016. Berdasarkan hasil proyeksi tahun 2036, jenis tutupan lahan yang paling banyak mengalami inkonsistensi adalah ruang terbangun, pertanian lainnya, dan sawah seperti halnya inkonsistensi pada tahun 2016. Sawah, lahan pertanian lainnya, dan ruang terbangun diproyeksi mengalami inkonsistensi pada kawasan lindung, hutan produksi, serta pertanian lahan basah dan kering. Peluang inkonsistensi yang sebesar $17.53 \%$ tersebut harus terus dikurangi dengan berbagai instrumen pengendalian pemanfaatan ruang, 
seperti: peraturan zonasi, perizinan, mekanisme insentif-disinsentif, serta penerapan sanksi. Implementasi pemanfaatan ruang harus diupayakan selaras dengan RTRW agar tercipta lingkungan yang lestari dan berkelanjutan.

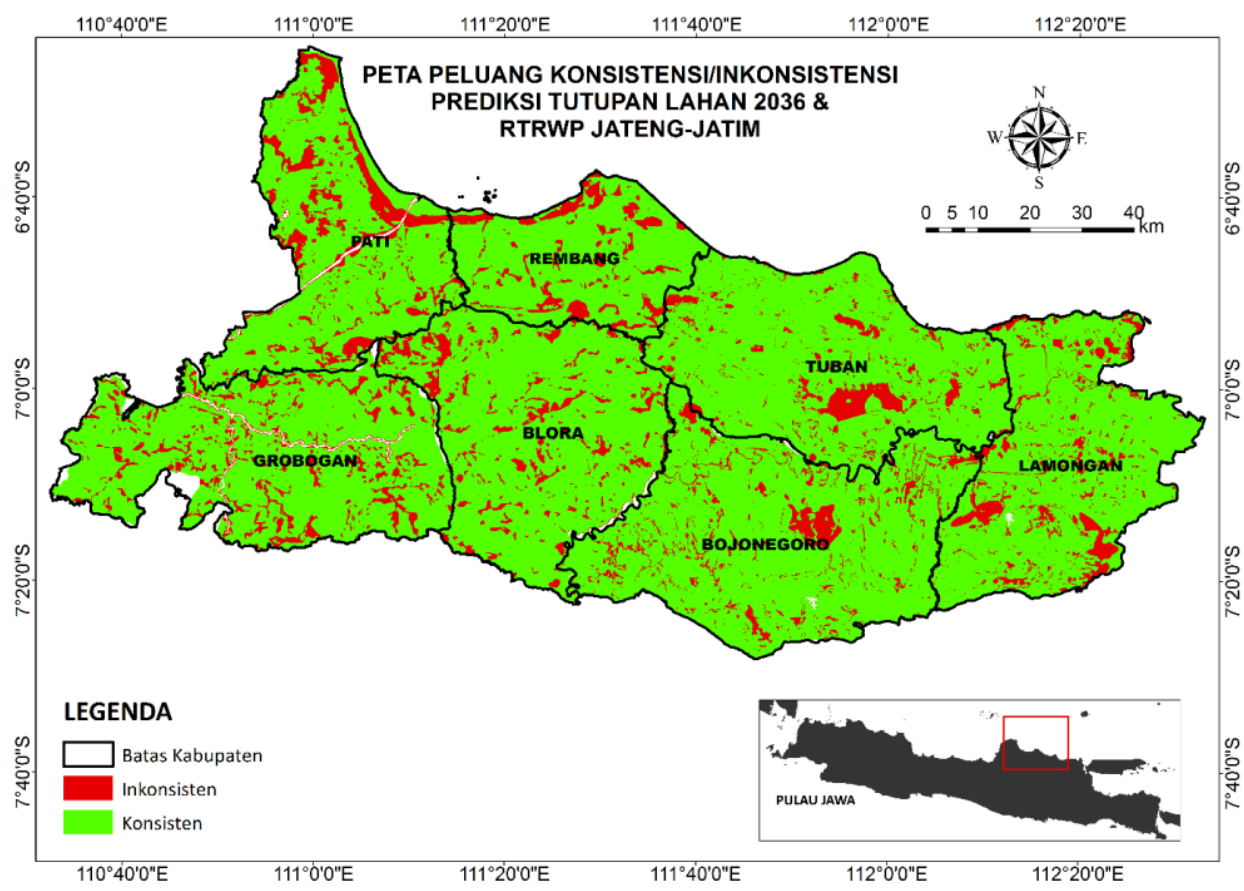

Gambar 9. Peluang inkonsistensi tutupan lahan tahun 2036* dengan RTRW Provinsi Jateng dan Jatim

Tabel 8. Peluang inkonsistensi tutupan lahan hasil proyeksi tahun 2036 dengan RTRWP Jateng dan Jatim (7 kabupaten)

\begin{tabular}{llll}
\hline Tutupan Lahan 2036 & RTRW & Luas (ha)* & $\begin{array}{l}\text { Luas } \\
\text { (ha)** }\end{array}$ \\
\hline Ruang terbangun & Kawasan Lindung & 4,091 & 1,299 \\
& Hutan Produksi & 6,407 & 2,187 \\
& Badan Air & 52 & - \\
& Sawah/Pertanian Lahan Basah & 41,338 & 3,357 \\
& Pertanian Lahan Kering & 10,161 & 2,548 \\
\hline Sawah & Kawasan Lindung & 13,632 & 7,117 \\
\hline Pertambangan & Kawasan Lindung & 85 & 50 \\
& Hutan Produksi & 2,425 & 2,092 \\
& Sawah/Pertanian Lahan Basah & 598 & 233 \\
& Pertanian Lahan Kering & 240 & 222 \\
\hline Badan Air & Kawasan Lindung & 1,821 & 9 \\
& Hutan Produksi & 312 & 5 \\
& Sawah/Pertanian Lahan Basah & 8,748 & 75 \\
& Pertanian Lahan Kering & 1,087 & 8 \\
& Ruang terbangun & 4,959 & 1 \\
& Kawasan Peruntukan Industri & 190 & 1 \\
\hline Pertanian Lainnya & Kawasan Lindung & 15,419 & 6,172 \\
& Hutan Produksi & 33,167 & 14,765 \\
\hline Luas (peluang inkonsisten) ha & & 170,060 & 48,305 \\
\hline Keterangan: *Wilayah Agregat $* *$ Pegunungan Kendeng & &
\end{tabular}

\section{KESIMPULAN}

1. Tutupan lahan baik di wilayah agregat maupun Pegunungan Kendeng mengalami dinamika perubahan tutupan lahan dari tahun 1996 hingga 2016. Tutupan lahan yang luasnya cenderung menurun adalah hutan, sawah, pertanian lainnya. Luas tutupan lahan yang cenderung meningkat 
adalah pertambangan, ruang terbangun, dan badan air.

2. Pada dua puluh tahun mendatang yaitu tahun 2036, tren dinamika perubahan tutupan lahan tahun 1996-2016 semakin jelas terlihat. Tutupan lahan hutan, sawah, dan pertanian lainnya terus mengalami penyempitan luas, sedangkan tutupan lahan pertambangan, ruang terbangun, dan badan air diproyeksi luasannya semakin meningkat. Namun pada Pegunungan Kendeng, badan air luasnya semakin menyempit.

3. Inkonsistensi tutupan lahan tahun 2016 yaitu $12.53 \%$ (wilayah agregat) dan $16.80 \%$ (Pegunungan Kendeng). Peluang inkonsistensi tutupan lahan tahun 2036 adalah $13.5 \%$ (di wilayah agregat) dan $17.53 \%$ (di Pegunungan Kendeng). Nilai inkonsistensi tutupan lahan terhadap RTRW Provinsi Jateng-Jatim terus meningkat khususnya inkonsistensi pertambangan sangat tinggi.

\section{SARAN}

Pemerintah daerah di wilayah Pegunungan Kendeng dan wilayah agregat sebaiknya melakukan koordinasi dalam melakukan mekanisme pengendalian pemanfaatan ruang secara nyata agar inkonsistensi tata ruang yang terjadi di wilayah Pegunungan Kendeng dan wilayah agregat dapat berkurang. Pengendalian ini juga diharapkan dapat menghentikan atau mengurangi laju peningkatan lahan terbangun dan pertambangan di wilayah Pegunungan Kendeng dan wilayah agregat.

\section{DAFTAR PUSTAKA}

Azadi, H., Ho, P., \& Hasfiati, L. (2011). Agricultural land conversion drivers: A comparison between less developed, developing and developed countries. Land Degradation and Development, 22 (6), 596-604.
[BSN] Badan Standardisasi Nasional. (2010). SNI 7645:2010 Klasifikasi Penutup Lahan. Badan Standardisasi Nasional.

Ditjen Penataan Ruang Kementerian PU. (2010). Pedoman pemantauan dan evaluasi pemanfaatan ruang wilayah kota berbasis sistem informasi geografis. Ditjen Penataan Ruang Kementerian PU.

Firman, T. (2004). Major issues in Indonesian's urban land development. Land Use Policy, 21, 347-355.

Firman, T. (2000). Rural to urban land conversion in Indonesia during boom and bust periods. Land Use Policy, 17 (1), $13-20$

Hariyanto \& Tukidi. (2007). Konsep Pengembangan Wilayah dan Penataan Ruang Indonesia di Era Otonomi Daerah. Jurnal Geografi, 4 (1), 2-9.

Hartanto, D. A. \& Suyoto. (2017). Penanganan Kasus Penambangan Galian C Ilegal di Kawasan Pegunungan Kendeng Selatan dan Pegunungan Kendeng Utara di Kabupaten Pati. Prosiding Seminar Nasional Publikasi Hasil-hasil Penelitian dan Pengabdian Masyarakat "Implementasi Penelitian dan Pengabdian Masyarakat untuk Peningkatan Kekayaan Intelektual, 107122. Semarang.

Hidayat, W., Rustiadi, E. \& Kartodihardjo, H. (2015). Dampak Pertambangan terhadap Perubahan Penggunaan Lahan dan Kesesuaian Peruntukan Ruang (Studi Kasus Kabupaten Luwu Timur, Provinsi Sulawesi Selatan). Jurnal Perencanaan Wilayah dan Kota, 26 (2), 130-146.

Jing, W., Yifan, L., Glendinning, A., \& Yueqing, X., (2018). Land-use changes and land policies evolution in China's urbanization processes. Land Use Policy, 75, 375-387.

Kurnianti, D.N., Rustiadi, E., \& Baskoro, D. P. T. (2015). Land Use Projection for Spatial Plan Consistency in Jabodetabek. Indonesian Journal of Geography, 47 (2), 124-131. 
Kurniawan, I., Barus, B., \& Pravitasari, A. E. (2017). Pemodelan Spasial Perubahan Penggunaan Lahan di Taman Nasional Gunung Halimun Salak dan Daerah Penyangganya. Journal of Regional and Rural Development Planning (Jurnal Perencanaan Pembangunan Wilayah dan Perdesaan), 1 (3), 270-286.

Lamidi, Sitorus, S. R. P., Pramudya, B., \& Munibah, K. (2017). Land use change in rice fields in Serang City, Banten Province, Indonesia. International Journal of Science: Basic and Applied Research (IJISBAR), 36 (5), 345-351.

Lillesand, T. M. \& Kiefer, R. W. (1990). Penginderaan jauh dan interpretasi citra. Diterjemahkan oleh Dulbahri, P. Suharsono, Hartono dan Suharyadi. Gajah Mada University Press.

Lo, C. P. (1995). Penginderaan Jauh terapan. Penerbit Universitas Indonesia.

Mulya, S. P., Rustiadi, E., Chan, W. F., \& Pravitasari, A. E. (2019). Perubahan tutupan lahan dan keselarasan dengan kebijakan ruang di Sub DAS Ciliwung Hulu. Prosiding Nasional Seminar ASPI 2019.

Nurwanda, A., Zain, A. F. M., \& Rustiadi, E. (2015). Analysis of Land Cover Changes and Landscape Fragmentation in Batanghari Regency, Jambi Province. Procedia - Social and Behavioral Sciences, 227, 87-94.

Pemerintah Republik Indonesia. (2007). Undang-Undang Republik Indonesia No. 26 Tahun 2007 tentang Penataan Ruang. Sekretariat Negara.

Pravitasari, A. E., Suhada, A., Mulya, S. P., Rustiadi, E., Murtadho, A., Wulandari, S., \& Widodo, C. E. (2019). Land Use/Cover Change and Spatial Distribution Pattern of Rice Field Decreasing Trend in Serang Regency, Banten Province. The 1st International Seminar on Natural Resources and Environmental Management (ISeNREM 2019). IOP Conference Series: Earth and Environmental Science. 1-11.
Rahayu, J., Utami, T. W., \& Wasono, R. (2016). Pemodelan Kualitas Air di Kawasan Pegunungan Kendeng dengan Pendekatan Ordinary Kriging dan Geographic Information System (GIS). Statistika, 4 (2), 46-51.

Ricky, Rustiadi, E. \& Barus, B. (2017). A Projection of Land Needed for Settlements and Conversion of Paddy Fields in Solok City. Journal of Regional and City Planning, 28 (3), 186-203.

Setiawan, H., Sudarsono, B., \& Awaluddin, M. (2013). Identifikasi Daerah Prioritas Rehabilitasi Lahan Kritis Kawasan Hutan dengan Penginderaan Jauh dan Sistem Informasi Geografis. Jurnal Geodesi Undip, 2 (3), 31-41.

Widjayatnika, B., Baskoro, D. P. T., \& Pravitasari, A. E. (2017). Analisis Perubahan Penggunaan Lahan dan Arahan Pemanfaatan Ruang untuk Pertanian di Kabupaten Penajam Paser Utara, Provinsi Kalimantan Timur. Journal of Regional and Rural Development Planning (Jurnal Perencanaan Pembangunan Wilayah dan Perdesaan), 1 (3), 243-257. 